enough that variations must be governed by some law. But as we are absolutely ignorant what that law is, he thought it allowable to make provisional use of the word accidental. But the "neo-Darwinians" (as Prof. Ray Lankester calls them) are not content with this dethronement of their idol, Fortuity. The supreme and everlasting rule of pure accident is their creed and worship. Hence comes Prof. Ray Lankester's simile of the kaleidoscope, by which he illustrates the genesis of "new characters" in organic life. There is, he indicates, no more connection between those "new characters" and their origin in the parent, than there is between the new patterns which tumble in a kaleidoscope and the tap upon the tube which shakes them out.

There is no argument so false as a false analogy. And this is a case in point. Every illustration or analogy must be false which confounds mere mechanical arrangement with organic structure. They are not only different, but they are different in kind. Neither mechanical aggregation, nor mechanical segregation, can possibly account for the building up of organic tissues. To attempt to account for such structures by causes similar to those which determine the arrangement of tumbling bits of glass, is even more irrational than it would be to account for the structure of a great cathedral by explaining to us how its bricks or its stones were made. There is one grand peculiarity in all organic structures which all such illustrations are framed to conceal. That grand peculiarity is this-that they are all made for work, for the discharge of some function. They are where they are not merely because somehow they have been put there. But they are what they are, and where they are, because they have some given work to do. But more than this: they all pass through stages of development in which their work cannot as yet be done. In all these stages, that work lies before them in respect to time, and behind them in respect to adaptation. They are all of the nature of an "apparatus." This is the word which the profound but unconscious metaphysic of human speech has invented for them. It is the word chosen by natural selection, and, as such, it ought to secure the homage even of Prof. Ray Lankester himself. The idea, however, comes before the word-shapes it, and inspires it-just as the needs of function, and the organic necessities imposed by inorganic laws, have shaped and inspired the growth and development of every organic apparatus.

I am very glad to see that under the stress of controversy the Professor admits-and even hotly denies that it has ever been doubted-that natural selection cannot account for the preexistence of the structures which are presented for its choice. And not only must selected organs exist before they can be chosen by natural selection, but they must have been already sufficiently developed to possess some functional activity. This was my contention thirty years ago, and to this day I have always found it either denied or evaded by the whole ultraDarwinian school. I rejoice to see it now admitted as unquestionable. "Natural selection can account for the origin of nothing"- so says Mr. Cope. The Professor indignantly replies: "How can Mr. Cope presume to tell us this?" Who has ignored it? when? and where?" So ends a long and a hard fight. The enemy not only lays down his arms, but denies he has ever carried them.

ARGYLL.

\section{Who Discovered the Teeth in Ornithorhynchus?}

IT is almost superfluous to add anything to Prof. Flower's reply (p. 15I) to Dr. Hart Merriam. In justice, however, to Mr. Poulton, it ought, I think, to be stated that he fully refers to Home's paper in the Philosophical Transactions. In the Quart. Fourn. Micr. Sci., vol. xxix. p. 27 (a paper to which Dr. Hart Merriam alludes as though he had read it) Mr. Poulton, describing the horny plates of Ornithorhynchus, writes as follows: "Home (Phil. Trans., I802, p. 71) correctly describes these horny plates as differing 'from common teeth very materially, having neither enamel nor bone, but being composed of a horny substance only embedded in the gum,' "\&c. I observe too, with great interest, that in the same paper Home makes use of the expression (p. 7o) "the teeth, if they can be so called." On p. $28 \mathrm{Mr}$. Poulton quotes in full the passage from Owen given by Prof. Flower. Perhaps Dr. Hart Merriam does not accept Owen's correction of Home's hypothesis. It is hardly necessary to point out that the teeth which Mr. Poulton describes (p. 15 et seq.) under the headings (I) tooth papilla; (2) dentine ; (3) enamel ; (4) inner epithelium of enamel organ; (5) stratum intermedium of Hannover; (6) middle membrane of enamel organ; and (7) outer membrane of enamel organ, must be very different from those which Home calls "cuticular," and further qualifies as in the sentence which I have quoted.

Comparison of Home's figures with Mr. Oldfield Thomas's (Proc. Roy. Soc., vol. xlvi. pl. 2) renders it highly probable that the true teeth of Home's younger specimen had only recently dropped out from the horny plates; the dimensions given by the two authors being almost identical. But Home's description is perfectly definite, and no hint whatever is made to true teeth situated upon the horny plates such as those described and figured by Mr. Oldfield Thomas. The length of the skull of Home's specimen, as given in his figure, is 71 millimetres, w hile that of Thomas's female specimen is 65 millimetres; the male is slightly larger. Probably, therefore, Home's specimen was considerably older than Thomas's, and had lost the true teeth for some little time.

The only conclusion at which I can arrive is that Dr. Hart Merriam did not read any of the three papers bearing on this subject with sufficient care and attention to enable him to fully understand the facts ascertained by their respective authors, if indeed he proceeded further than the introductory remarks prefacing Mr. Oldfield Thomas's communication to the Royal Society.

Oswald H. LatTer.

A natomical Depa:tment, Museum, Oxford, December 20.

\section{Galls.}

IN answer to $\mathrm{Mr}$. Ainslie Hollis, I should like to observe that, in my opinion, the theory of natural selection is not "seriously assailed by investigations into the formation of galls by insects." On the contrary, in reply to what appeared to be a challenge from Mr. Mivart, I pointed out the manner in which natural selection might here be fairly supposed to have operated. But, while doing this, it appeared desirable to add that the case is a highly peculiar one. If galls were merely amorphous tumours or even if they presented but as small an amount of specialization for the benefit of the larvæ as is presented by animal tissues for the benefit of their parasites, the case would not be so peculiar. But the degree of morphological specialization which the "pathological process" presents in the case of some gallsand this, of course, for the exclusive benefit of the contained parasites-is very remarkable. And although I dombt not that it is but a higher exhibition of the same principles as obtain in the case of animal tissues and their parasites, it is a case of much greater interest from the Darwinian point of view. For, if the explanation given in my last letter be accepted, the facts show how enormous must be the power of natural selection in building up adaptive structures, seeing that it can do this in so high a degree even when working, as it were, at the end of a long lever of the wrong kind-i.e. acting indirectly on the vege:able tissues through the benefits thereby conferred on their animal parasites. I am not aware that there is any other instance of "symbiosis" where so high a degree of adaptive specialization is presented by one of the "partners" for the exclusive benefit of the other.

London, December 13.

Mr. W. AInslie Hollis has involuntarily misrepresented me as saying that the theory of natural selection can be "seriously assailed" by investigations respecting galls. I said, indeed (NATURE, November I4, p. 4I), that it would be "very interesting to learn how" natural selection could have caused them; but I was careful to add that doubtless an explanatory hypothesis was ready to hand. I do not myself believe they were so caused ; but if they were not, they would none the less, like almost all biological phenomena, be explicable by an unlimited use of gratuitous hypotheses concerning physiological correlations and imaginary ancestors.

I confess I do not see that calling them "pathological" (an epithet I certainly would not deny them), and comparing them with inflammatory renal foci due to Bacilli, will explain them, unless it be affirmed that pathological conditions favourable to parasites are always due to the action of "natural selection" on the parasites themselves-an affirmation which appears to ask too much.

Herr Wetterhan's argument from symbiosis sins against natural selection itself. For that theory requires that, in the arduous and incessant struggle for life it supposes, any prejudicial growth should, in time, be eliminated unless carrying with it some preponderating advantage. The insect and the plant are 